\title{
Histories of media(ted) participation: An introduction
}

\author{
Nico Carpentier ${ }^{1}$ \\ Vrije Universiteit Brussel (VUB), Belgium, and Charles University in Prague, Czech Republic
}

\section{Peter Dahlgren}

Lund University, Sweden

\section{doi:10.5937/comman1430007C}

The attention spent on the notion of participation has oscillated over time and within different academic disciplines and societal fields. For instance, in democratic theory, where the notion of participation points to the citizens' inclusion in the dynamics of decision-making, it has maintained a presence over time, throughout the history of more than 200 years of democratic revolution (Mouffe, 2000), where political processes have been geared towards more participation and equality, despite many setbacks and concerns which were also discursified, this time as a lack of participation (or a "democratic deficit"). If we follow a Longue Durée approach (Braudel, 1969)—with some critical distance and the acknowledgement that this approach comes at a cost, namely the loss of specificity and detail — we see the role of royalty and aristocracy being undermined by a bourgeoisie claiming its place in society, a process followed by further waves of democratization linked to universal suffrage, but also by further efforts towards egalization within all societal fields.

Within media studies, in the recent years, participation re-established itself as a prominent concept, a process which is very much connected to the popularization of the internet, although this did not happen immediately. In a first (pre-web 2.0) phase, the two key signifiers of access and interaction gained dominance. Participation did not (completely) vanish from the theoretical

\footnotetext{
1 nico.carpentier@vub.ac.be
} 
scene, as especially the theoretical reflections on electronic (direct) democracy and new media offered a safe haven for participation. These elaborations partially continued the work of earlier participatory-democracy theorists such as Barber. For instance, in Strong Democracy Barber (1984: 289) focuses mainly on "interactive video communications", but already is referring in a balanced way to the potential participatory use of networked computers. Only later, in the 2000 s, in the web 2.0 phase, the concept of participation made a remarkable comeback to reach a prominent position.

At the same time, these 'new' technologies in many cases have led to formulations of strong claims to novelty and uniqueness, in combination with processes of amnesia in relation to the societal roles of old media technologies. As Ekström et al. (2011: 4) write: "by overstating the newness of participatory media, the history of audience activity [and media participation] is made invisible and the present elusively vague." Apart from the need for historical research for its own sake, and the need to show the complexities and differences over time by going back to periods "when old technologies where new" - to quote Marvin's (1988) book title - historical research is also very necessary to compensate for the mythologies of novelty that characterize contemporary reflections about 'new' - or better: online - media. Today's digital media landscape is of course in constant evolution, and it is important to understand how its patterns of development, not least in regard to its political economy, technical architecture, and socio-cultural usage, embody built-in contingencies that both engender and delimit its efficacy for democratic participation (Curran, Fenton and Freedman, 2012; Dahlgren, 2013).

This special issue took on this challenge to combine historical research with the study of participatory media. This is not new. One of us, for instance, published in 2011 a rather detailed study of the first interactive film, Kinoautomat-One man and his house (1967), which was featured in the Czechoslovak pavilion of the 1967 International and Universal Exposition (Expo 67) in Montréal, Canada (Carpentier, 2011). During the projection of this film, spectators could influence the film's storyline by voting for one of two possible storylines. The film theatre armchairs were equipped with voting technology, and a basic computer processed the votes. Despite its many limitations, which pushed it towards more minimalist forms of participation, Kinoautomat showed that also more unlikely communication technologies (such as film) could be used 
to organize processes of audience decision-making, and that these participatory processes were organized as early as the 1960s (within the realm of film). Moreover, both editors have also collaborated with Francesca Pasquali - one of the authors in this special issue - in developing genealogies of media and political participation, which have heavily influenced this text (Carpentier, Dahlgren and Pasquali, 2013; Carpentier, Dahlgren and Pasquali, 2014).

As always, other colleagues also helped pave the way. Above we already referred to Ekström et al.'s (2011) introduction of the edited volume History of Participatory Media. Politics and publics, 1750-2000. This very valuable contribution to the history of media participation uses a broad approach to media, incorporating participatory practices in relation to, for instance, fun fairs, exhibitions, cylinder phonographs, photocopies and museums. On the downside, and although the book mobilizes the theoretical distinction between interactivity and participation (mostly in its introduction, but also in some chapters, e.g. Axelsson, 2011), it uses a very broad approach towards participation, also including processes where participants hardly have any control ${ }^{2}$.

\section{A brief definition of participation}

In this special issue, a more restrictive definition of participation is preferred and applied. The concept of participation, refers - according to us - to a situation where the actors involved in (formal or informal) decision-making processes are positioned towards each other through power relationships that are (to some extent) egalitarian.

This political approach to (the definition of) participation places significant emphasis on power sharing as a defining characteristic of participation. Arnstein's (1969) ladder of participation is a prime example of this approach. In her seminal $A$ Ladder of Citizen Participation article, she linked participation explicitly to power, saying "that citizen participation is a categorical term for citizen power" (Arnstein, 1969: 216). She continued:

\footnotetext{
2 One particular example is Wisselgren's (2011) chapter in this book, which discusses "reality TV as a participatory medium with a special focus on its social experimental character" (Wisselgren, 2011: 143). Although the chapter critically evaluates the difference between inviting "the audience to affect the outcome of the programme" and making "it possible to switch roles and become a participants" on the one hand and "sharing the power of the heavily capitalized global media industry" (Wisselgren, 2011: 154) on the other, it still uses the label of "participatory media" for these often exploitative media practices.
} 
It is the redistribution of power that enables the have-not citizens, presently excluded from the political and economic processes, to be deliberately included in the future. It is the strategy by which the have-nots join in determining how information is shared, goals and policies are set, tax resources are allocated, programs are operated, and benefits like contracts and patronage are parceled out. (Arnstein, 1969: 216)

Arnstein developed a categorization of participation (the 'ladder'), in which she distinguished three main categories (citizen power, tokenism, nonparticipation) and eight levels. The category of non-participation consists of two levels: manipulation and therapy. Tokenism has three levels, informing, consultation and placation. The last category is citizen power, which has three levels: partnership, delegated power and citizen control. This useful categorization system allows her to distinguish between processes that are participatory, and processes that are not (tokenism and non-participation).

Another classic definition of participation that emphasizes the defining characteristic of power was developed by Pateman in her 1970 book Democratic Theory and Participation. Pateman distinguished between partial and full participation, where partial participation is defined as "a process in which two or more parties influence each other in the making of decisions but the final power to decide rests with one party only" (Pateman, 1970: 70). Full participation is seen as "a process where each individual member of a decision-making body has equal power to determine the outcome of decisions" (Pateman, 1970: 71). While such a process might at first glance be dismissed as utopian, we would argue that it not only shows the importance of power in defining participation, but that it also remains a fundamental normative vision within democratic thought. Democracy itself embodies a utopian dimension, yet those who value democracy do not dismiss it out of hand; its normative vision serves as a compass for political strategy and agency. What Pateman and other theorists inject is an analytic component that operates in tandem with the normative one, and it pivots on the notion of power.

Hearn (2012), in his critical review of the major theories about power, reminds us that power relations are not equally distributed throughout society, but that power becomes concentrated in various centres. It is what he calls 'dispositional'; it has structure. At the same time, however, he asserts a dialectical perspective of structure and agency: "Power is not matter of agency versus 
structure, but of agencies in structure, which is part of the account of its variable distribution" (Hearn, 2011: 211-212). Various kinds of power structures can thus be understood as comprizing the major contingencies for participation. He further distinguishes between 'power to' and 'power over', which highlights the relationship between participation as agency and the structures of power relations in which it is embedded. Lastly, Hearn contrasts asymmetrical power with balanced power, underscoring the normative democratic ideals of checks, balances and accountability, as well as the view that the power of domination can and should be confronted by counter-power - which not least takes the form of participation.

\section{The research projects in this special issue}

These logics of struggle, for instance, also apply to the cultural/symbolic realm and the media sphere, and their political dimension should be acknowledged. In other words, the representational is itself political and an arena of the participatory power struggle.

The six articles in this special issue are a modest contribution to further our knowledge about the history of media participation. Embedded within the work of the Audience interactivity and participation Working Group 2 of the Transforming Audiences, Transforming Societies Cost Action, they all focus on the $20^{\text {th }}$ and $21^{\text {st }}$ century histories of participation. Moreover, half of them write contextualized histories of the digital. Arguably, this is an indication that it might be time to abandon the concept of 'new media' and replace it by 'online media' and/or 'digital media'. But these articles are also indicators of the importance of writing histories of the internet, connecting them with the analyses of other societal evolutions.

Amongst the three articles that focus on the digital, is first of all Francesca Pasquali's For an archeology of online participatory literary writing, which deals with the history of hypertext (and hyperfiction). Secondly, Dennis Beckers and Peter van den Besselaar analyze the history of Amsterdam's three digital cities in The tales of the three digital cities of Amsterdam: The application of ICT for social and political participation. And finally, also Igor Vobičs article, Historicising the journalist-audience relationships in the internet era: A case study of the Slovenian newspaper Delo, is situated in the digital era, with its analysis of how a Slovenian news paper has organized audience participation and conceptualized their 
audience(s) from the mid-1990s onwards. These three articles each show, in their own ways, the interconnections between the online and different other societal fields, such as the cultural, the political and the journalistic. Moreover, they also demonstrate the complexities, fluidities and limitations of specific participatory practices.

The three other articles in this special issue move towards earlier media forms. Fausto Colombo's article, Wrong turns towards revolution? Grassroots media and political participation in Italy (1967-2012), takes a long-term and bird's eye perspective on the connection between political and media participation, paying attention to a variety of media, including film, radio and the internet. In Fighting for a regime change through active listening, Nelson Ribeiro analyzes the ways that Portuguese listeners interacted with the BBC during World War II, in their attempts to change the broadcasting policies and content. The last article, Propaganda, critical media literacy and participation: Tracing memories of the Soviet media, by Natalija Mažeikienè and Kristina Juraite, shifts the attention to a history where participation was not allowed, and analyzes how some of the prerequisites of participation were still present. Again, in these articles we can also find the complexities of participation, combined with the hopes and disappointments that participatory processes inevitably entail. 


\section{References}

Arnstein, S. R. (1969). A ladder of citizen participation. Journal of the American Institute of Planners, 35(4), 216-224.

Axelsson, B. (2011). History on the web. Museums, digital media, and participation. In Ekström, A., Jülich, S., Lundgren, F. \& Wisselgren, P. (eds.), History of participatory media. Politics and publics. New York: Routledge, pp. 159-172.

Barber, B. (1984). Strong democracy. Participatory politics for a new age. Berkeley: University of California Press.

Braudel, F. (1969). Écrits sur l'Histoire [Writings on history]. Paris: Flammarion.

Carpentier, N., Dahlgren, P. \& Pasquali, F. (2013). Waves of media democratization. A brief history of contemporary participatory practices in the media sphere. Convergence, 19(3), 287-294.

Carpentier, N., Dahlgren, P. \& Pasquali, F. (2014). The democratic (media) revolution: A parallel history of political and media participation." In Carpentier, N., Schrøder, K. \& Lawrie, H. (eds.), Audience transformations. Shifting audience positions in late modernity. London: Routledge, pp. 123-141.

Carpentier, N. (2011). Media and participation. A site of ideological-democratic struggle. Bristol: Intellect.

Curran, J., Fenton, N. \& Freedman, D. (2012). Misunderstanding the Internet. Abington: Routledge.

Dahlgren, P. (2013). The political web: Media, participation and alternative democracy. Basingstoke: Palgrave.

Ekström, A., Jülich, S., Lundgren, F. \& Wisselgren, P. (2011). Participatory media in historical perspective: An introduction. In Ekström, A., Jülich, S., Lundgren, F. \& Wisselgren, P. (eds.), History of participatory media. Politics and publics. New York: Routledge, pp. 1-9.

Hearn, J. (2012). Theorizing power. Basingstoke: Palgrave/Macmillan. 
Marvin, C. (1988). When old technologies were new: Thinking about electric communication in the late nineteenth century. New York: Oxford University Press.

Mouffe, C. (2000). The democratic paradox. London: Verso.

Pateman, C. (1970). Participation and democratic theory. Cambridge: Cambridge University Press.

Wisselgren, P. (2011). Expedition Robinson, reality TV, and the history of the social experiment. In Ekström, A., Jülich, S., Lundgren, F. \& Wisselgren, P. (eds.), History of participatory media. Politics and publics. New York: Routledge, pp. 142-157. 